\title{
Students Engagement Variables as Correlates of Academic Achievement in Economics in Senior Secondary Schools in Anambra State, Nigeria
}

\author{
Ohamobi Ifunanya N. ${ }^{1}$, Ezeaku, Stella N. ${ }^{2}$ \\ Department of Educational Foundations, Faculty of Education, Chukwuemeka Odumegwu Ojukwu University, Igbariam Campus
}

\begin{abstract}
Evidence of poor academic achievement of senior secondary school students abounds in literature and can be seen in the rate of failure of students in the national examinations organised by WAEC, NECO and JAMB. Achievement is likely to be enhanced if students are engaged. Student engagement, which is the students' psychological investment in an effort directed towards learning, understanding or mastering the knowledge, skills or crafts that academic work is intended to promote, has been identified as one of the few factors that consistently and positively influence educational outcomes for adolescents. The more engaged a student is, the better he performs at school. The purpose of this study was to compare the levels of engagement of students with their cognitive (academic) achievement in Economics in secondary schools in Anambra State. Guided by three research questions and three hypotheses, the study adopted a correlation Survey Design. The population for the study comprised 4,937 students of senior secondary schools in Anambra State. Out of this, a sample size of 200 students in 10 boys' schools and 10 girls' schools was taken. The Student Engagement Questionnaire (SEQ), measuring the three engagement types and as well as Economics Achievement Test (EAT) were used for data collection. The reliability index was determined using Factor Analysis. Data were collected and analyzed using aggregate scores and mean to answer the research questions and the regression analysis to test the hypotheses at 0.05 level of significance. The findings showed among others that there is a high engagement among senior secondary school students in the state. Since the three engagement types had mean scores above 2.50, it is therefore concluded that the more engaged a student is, the better he/she achieves in school. Out of the three engagement types measured, the students reported moderate in cognitive but high in behavioural and emotional engagements. One can therefore conclude that moderate engagement may be sufficient for a good academic achievement. It was thus recommended among others that a campaign which focuses on the importance of school and the consequences of disengagement from school be carried out regularly by the government agencies and other stakeholders in education. If students can be made to see the link between working hard at school and being successful in life, engagement levels will be significantly raised and academic achievement be greatly enhanced.
\end{abstract}

Keywords: Engagement; Variables; Academic Achievement; Economics; and Senior Secondary Schools.

\section{Introduction}

Education is widely acknowledged as a tool for national development. Not only is it the greatest force that can be used to bring about redress, it is the greatest investment that the nation can make for quick development of its economic, political, sociological and human resources. (Fafunwa, 2001) Furthermore, education is seen as an instrument for individual and social development. The future of any nation depends to a very large extent on the products of its educational system. This underscores the need for the right kind of education which will in turn produce people who are adequately prepared "for useful living within the society" (Federal Republic of Nigeria, 2004:18).

For students to be adequately prepared for useful living within the society and also for the secondary school students to advance into institutions of higher learning there has to be an acceptable level of academic achievement on the part of these students. For there to be an acceptable level of academic achievement (performance), there has to be meaningful learning and for meaningful learning to take place, the students have to be fully engaged. In other words, if students are to live happy and productive lives in the complex world of the $21^{\text {st }}$ century, students need to achieve a wide range of schooling outcomes. Achievement is likely to be enhanced if students are engaged and motivated to learn (Education Review Office. $n \mathrm{~d}$ ).
The term student engagement refers to "a psychological process, specifically; the attention, interest and investment and effort students expend in the work of learning" (Marks, 2000:153). Students are engaged when they are involved in their work, persist despite challenges and obstacles, and take visible delight in accomplishing their work.

There are three types of engagement: behavioural, cognitive and emotional. Anderson, Christenson and Lehr (2004:65) stated that;

Engagement is much more than time students spend on task: rather, students' engagement with school and learning includes their behaviour (eg attendance and participation), cognition (eg value of education, relevance to future, selfregulation), and psychological/ interpersonal experiences (eg feeling that he or she belongs at school, relationships with teachers and peers).

Student engagement with school represents a common term to describe student relationship with school. It is one of the terms and variables used to measure student and school relationships. Other related terms to student engagement in health and education literature include; school attachment, school bonding, school climate, school involvement, school engagement, teacher support and school connectedness,(Libbey, 2004). All these terms are used to describe students who are intellectually, socially, and emotionally engaged with school. Student engagement is used to discuss students' attitudes towards school while 


\section{International Journal of Science and Research (IJSR) \\ ISSN (Online): 2319-7064 \\ Index Copernicus Value (2013): 6.14 | Impact Factor (2015): 6.391}

student disengagement identifies withdrawing from school in any significant way, (Willms, 2003). Student engagement has been identified by Anderson, et al., (2004), as the most important concept in preventing school dropout or promoting completion. Lack of engagement with school is seen as a cause for early school leaving and reduces the likelihood of going on to further education. This has obvious consequences as failure to obtain even the most basic educational credentials (academic achievement) or acquire the basic skills needed to function in the society which increases dramatically the risk of unemployment, poverty, poor health, and involvement in crime.

In educational institution, success is measured by academic achievement or how well a student meets set standards. In other words, a student's success is generally judged by examination performance while the best criterion of performance is the sum of the students' performance in all the subjects taken.

Academic achievement is commonly measured by examinations or continuous assessment tests. But there is no general agreement on how it is best tested or which aspects are most important. The pattern of grading students in the Senior School Certificate Examination is such that Distinction is represented by A1, B2 and B3. The Credit grade is represented by $\mathrm{C} 4, \mathrm{C} 5$ and $\mathrm{C} 6$; the ordinary Pass is represented by $\mathrm{D} 7$ and $\mathrm{D} 8$, while the Failure grade is represented by F9 (WAEC, 2006). It's important to mention that the distinction and credit grades represent quality pass and are the only acceptable grades for admission into Nigerian universities. The minimum entry requirement is credits in five subjects including English language (JAMB, 2008). Economics as a subject is therefore considered appropriate in this project because it is a core subject (compulsory) that every student in secondary school is expected to offer and that it is not seen as a difficult subject people have phobia for.

Based on the discourse above, certain facts can logically be arrived at. First, education centres on the individual and perhaps the greatest indication of the quality of education is the quality of output which is the individual. Academic achievement and success are indications of the quality of the output. Student engagement is a pre-requisite for students' academic achievement and success. In order for students to learn and be successful, they need to be engaged in their school. Engagement is ensured if students appreciate and put forth effort in their school work, engagement is heightened when students follow rules and regularly attend all their classes.

It is therefore crucial for student engagement surveys to be carried out and for information pertaining to academic achievement of students to be obtained so that their academic achievement can be compared against their engagement levels. The determination of students' academic achievement is a comparative endeavour. Data on a range of indicators of both student engagement and students' academic achievement are processed and will thus be used to inform whole school improvement and better products. When this is done, the ultimate goal of education and the National Policy on Education may be achieved. The problem of this study therefore is, to establish the relationship between student engagement and their academic achievement in Economics in senior secondary schools in Anambra State, Nigeria.

\section{Research Questions}

The following research questions guided the study.

1) How does students' behavioural engagement determine their cognitive achievement in economics in Anambra State?

2) How does students' cognitive engagement determine their cognitive achievement in economics in Anambra State?

3) How does students' emotional engagement determine their cognitive achievement in economics in Anambra State?

\section{Hypotheses}

The following null hypotheses were formulated to guide the study and were tested at 0.05 level of significance.

1) There is no significant relationship in the mean scores of students between their behavioural engagement and cognitive achievement in Economics in Anambra State.

2) There is no significant relationship in the mean scores of students between their cognitive engagement and cognitive achievement in Economics in Anambra State.

3) There is no significant relationship in the mean scores of students between their emotional engagement and cognitive achievement in Economics in Anambra State.

\section{Method}

This study was carried out in Anambra State. It employed a correlation design in which the level of student engagement as compared to their academic achievement in Economics in secondary schools in Anambra State was observed. The population of the study comprised the four thousand, nine hundred and thirty-seven $(4,937)$ students $(2,013$ male \& 2,924 female) of senior secondary schools in the State. Using a purposive and proportionate stratified sampling technique, 200 students which comprised 100 male students from 10 single-boys' schools and another 100 female students from 10 single-girls' schools, were selected. Having determined the number of schools and the schools that have the required respondents, the students for the study were selected using simple random sampling technique.

The 30-itemed Students' Engagement Questionnaire (SEQ), measuring the three engagement types as well as 40questioned Economics Achievement Test (EAT) were the instruments used for the study. The SEQ which is a psychological sealed Likert- type was adequately faced validated by three experts, likewise the EAT. The SEQ instrument was initially administered to thirty (30) students in a trial testing. Data collected were first used for factor analysis by variance matrix principal component. Six items were dropped for poor loading. The instrument now has thirty items whose data were used to determine the approach. By this analysis, a reliability coefficient of 0.95 was obtained which was adjudged to be of high internal consistency. Also, the reliability of EAT which is a multiple choice (objective) test in four options with one correct option was obtained using test-re-test based on the 


\section{International Journal of Science and Research (IJSR) ISSN (Online): 2319-7064 \\ Index Copernicus Value (2013): 6.14 | Impact Factor (2015): 6.391}

Pearson Product Moment Correlation (PPMC). By this approach, a reliability coefficient for EAT was obtained as 0.97 using data obtained in two separate instruments administration on thirty students. All instrument administration for determination of reliabilities was done in Enugu State.

The researchers with the help of 5 trained research assistants distributed and retrieved the 200 copies of the questionnaire for the study. The data collected were analysed using aggregate scores and mean to answer the research questions and the regression analysis to test hypotheses 1 to 3 at 0.05 level of significance.

\section{Results}

Research Question 1: How does students' behavioural engagement determine their cognitive achievement in economics in Anambra State?

Table 1: Mean Ratings of Students on Behavioural Engagement

\begin{tabular}{|c|c|c|c|c|c|c|c|}
\hline S/NO & Item & $\mathbf{S A}$ & $\mathbf{A}$ & $\mathbf{D}$ & SD & $\mathbf{X}$ & Interpretation \\
\hline 1 & Easily pay attention in class. & 127 & 54 & 14 & 5 & 3.51 & Accepted \\
\hline 2 & Often get into trouble school. & 78 & 63 & 45 & 14 & 3.02 & Accepted \\
\hline 3 & Always do my homework promptly. & 77 & 88 & 28 & 7 & 3.18 & Accepted \\
\hline 4 & Do not get to school earlier than $8.00 \mathrm{am}$ & 55 & 60 & 70 & 15 & 2.77 & Accepted \\
\hline 5 & Do not get along with other students. & 53 & 82 & 40 & 25 & 2.81 & Accepted \\
\hline 6 & Participate in extra-curricular activities. & 91 & 71 & 27 & 11 & 3.21 & Accepted \\
\hline 7 & Skip classes during school hours. & 68 & 67 & 42 & 23 & 2.9 & Accepted \\
\hline 8 & Always present at morning assembly & 63 & 80 & 36 & 21 & 2.92 & Accepted \\
\hline 9 & Remain in school until school is over & 62 & 95 & 33 & 10 & 3.04 & Accepted \\
\hline 10 & Study at home even when I do not have a test & 46 & 71 & 49 & 34 & 2.64 & Accepted \\
\hline & Grand Mean & & \multicolumn{4}{|c|}{$\begin{array}{r}3.00 \\
\end{array}$} & Accepted \\
\hline
\end{tabular}

From results in table 1, all items are accepted as confirming students' behaviour because they have mean values above 2.50 , the limiting point. Even the grand mean is 3.00 which is above 2.50 , hence, the respondents agree that behavioural engagement determines their cognitive achievement.
Research Question 2: How does students' cognitive engagement determine their cognitive achievement in economics in Anambra State?

Table 2: Mean Ratings of Students on Cognitive Engagement

\begin{tabular}{|c|c|c|c|c|c|c|c|}
\hline S/NO & Item & SA & A & D & SD & X & Interpretation \\
\hline 11 & Do not think education is important & 34 & 63 & 56 & 47 & 2.4 & Not Accepted \\
\hline 12 & Learning in school will be useful to me later in life. & 60 & 85 & 32 & 23 & 2.91 & Accepted \\
\hline 13 & I think about my school work even when I am not in school. & 52 & 90 & 31 & 17 & 2.98 & Accepted \\
\hline 14 & A good school certificate result is important to me. & 103 & 52 & 33 & 12 & 3.23 & Accepted \\
\hline 15 & Do not wish to further my education. & 30 & 76 & 48 & 46 & 2.45 & Not Accepted \\
\hline 16 & Learn a lot from my classes. & 46 & 81 & 37 & 36 & 2.68 & Accepted \\
\hline 17 & Interested in the work I do in my classes. & 91 & 63 & 22 & 24 & 3.1 & Accepted \\
\hline 18 & Not important to attend school every school day. & 30 & 70 & 40 & 60 & 2.35 & Not Accepted \\
\hline 19 & Sometimes feel like staying away from school & 23 & 34 & 48 & 95 & 1.92 & Not Accepted \\
\hline & Grand Mean 2.66 & & & & & & Accepted \\
\hline
\end{tabular}

From the results in table 2 , items $12,13,14,16$ and 17 were accepted while items $11,15,18$ and 19 were not accepted. However, the grand mean of 2.66 implies that respondents agree that cognitive engagement determines their cognitive achievement.

Table 3: Mean Rating of Students on Emotional Engagement

\begin{tabular}{|c|c|c|c|c|c|c|c|}
\hline S/NO & Item & $\mathbf{S A}$ & $\mathbf{A}$ & D & SD & $\mathbf{X}$ & Interpretation \\
\hline 20 & It is fun to be in my school & 68 & 77 & 29 & 26 & 2.93 & Accepted \\
\hline 21 & Not happy to be at my school. & 41 & 63 & 43 & 53 & 2.46 & Not Accepted \\
\hline 22 & Teachers in my school do not treat students fairly. & 46 & 52 & 65 & 37 & 2.63 & Accepted \\
\hline 23 & Teachers care about how I'm doing & 94 & 85 & 14 & 7 & 3.33 & Accepted \\
\hline 24 & Working in school does not excite me. & 75 & 81 & 36 & 8 & 3.11 & Accepted \\
\hline 25 & I go to my teachers to discuss my personal problems. & 63 & 68 & 38 & 31 & 2.81 & Accepted \\
\hline 26 & Feel close to people in my school. & 72 & 65 & 35 & 28 & 2.9 & Accepted \\
\hline 27 & Do not feel safe in my school. & 7 & 79 & 88 & 26 & 2.33 & Not Accepted \\
\hline 28 & Have many friends at school. & 62 & 128 & 7 & 3 & 3.24 & Accepted \\
\hline 29 & Enjoy the work I do in class. & 63 & 125 & 8 & 4 & 3.23 & Accepted \\
\hline 30 & Classes are not boring. & 63 & 126 & 5 & 6 & 3.23 & Accepted \\
\hline \multicolumn{7}{|c|}{2.92} & Accepted \\
\hline
\end{tabular}

Research Question 3: How does students' emotional engagement determine their cognitive achievement in economics in Anambra State? 


\section{International Journal of Science and Research (IJSR) \\ ISSN (Online): 2319-7064 \\ Index Copernicus Value (2013): 6.14 | Impact Factor (2015): 6.391}

Results as shown in table 3 indicate that all items were accepted except items 21 and 27 for having mean values less than 2.50. But the grand mean of 2.92 is above 2.50 and so implies that students emotional engagement determines their cognitive achievement.

H01: There is no significant relationship in the mean scores of students between their behavioural engagement and cognitive achievement in Economics in Anambra State.

Table 4: Regression Summary of Students' Behavioural Engagement and Achievement Relationship

\begin{tabular}{|ll|}
\hline Multiple & $=0.21179$ \\
R Square & $=0.04494$ \\
Adjusted R Square & $=0.029$ \\
Standard Error & $=15.25840$ \\
\hline
\end{tabular}

$$
\mathrm{F}(1,118)=12.917 ; \mathrm{P}<0.05
$$

Table 5: ANOVA Results on Students’ Behavioural Engagement and Achievement Relationship

\begin{tabular}{|c|c|c|c|c|c|}
\hline Variables & $\begin{array}{l}\text { Sum of } \\
\text { Square }\end{array}$ & $D f$ & $\begin{array}{c}\text { Mean } \\
\text { Square }\end{array}$ & $\begin{array}{c}F \\
\text { ratio } \\
\end{array}$ & Significance \\
\hline Regression & 679.226 & 1 & 679.226 & & \\
\hline Residual & 14434.758 & 118 & 232.818 & 12.91 & 0.0000 \\
\hline Total & 15113.98 & 119 & & 1 & \\
\hline
\end{tabular}

Results in table 4 shows that behavioural achievement relationship has a multiple correlation of 0.211 in economics. However, this variable contributed only $2.95 \%$ of the variance in students achievement as shown by the coefficient of determination $(\mathrm{R} 2=0$. 029). The F-value shown below the table 4 explains the significance as stated by the ANOVA result in table 5, which is adjudged significant. Hence, there is a significant relationship in the mean responses of student between behavioural engagement and achievement in Economics.

H02: There is no significant relationship in the mean scores of students between their cognitive engagement and cognitive achievement in Economics in Anambra State.

Table 6: Regression Summary of Students Cognitive Engagement and Achievement Relationship

$\begin{array}{lr}\text { Multiple } & =0.0231 \\ \text { R Square } & =0.0005 \\ \text { Adjusted R Square } & =0.0141 \\ \text { Standard Error } & =15.2374\end{array}$

$\mathrm{F}(1,118)=22.36 ; \mathrm{P}<0.05$

Table 7: ANOVA Results on Students' Cognitive Engagement and Achievement Relationship

\begin{tabular}{|c|c|c|c|c|c|}
\hline Variables & $\begin{array}{c}\text { Sum of } \\
\text { Square }\end{array}$ & $D f$ & $\begin{array}{c}\text { Mean } \\
\text { Square }\end{array}$ & F ratio & Significance \\
\cline { 1 - 4 } Regression & 8.47729 & 1 & 8.47729 & & \multirow{2}{*}{32.824} \\
\hline Residual & 15788.1655 & 118 & 232.17891 & 0.0016 \\
\hline Total & 15796.64 & 119 & & \\
\hline
\end{tabular}

Results in table 6 reveal a multiple correlation of 0.0231 for cognitive achievement relationship in Economics. This figure contributes only $1.41 \%$ to the variance in students achievement as shown by $\mathrm{R} 2=0.0141$. The $\mathrm{F}$ value at the base of table 6 explains the significance which is stated in table 7 as significant. Therefore, there is a significant relationship between cognitive engagement and achievement of students in Economics.

H03: There is no significant relationship in the mean scores of students between their emotional engagement and cognitive achievement in Economics in Anambra State.

Table 8: Regression Summary of Students' Emotional Engagement and Achievement Relationship

\begin{tabular}{|lr|}
\hline Multiple & $=0.17319$ \\
R Square & $=0.02999$ \\
Adjusted R Square & $=0.01484$ \\
Standard Error & $=15.21113$
\end{tabular}

$\mathrm{F}(1,118)=38.072 ; \mathrm{P}<0.05$

Table 9: ANOVA Result of Students' Emotional Engagement and Achievement Relationship

\begin{tabular}{|c|c|c|c|c|c|}
\hline Variables & $\begin{array}{c}\text { Sum of } \\
\text { Square }\end{array}$ & $D f$ & $\begin{array}{c}\text { Mean } \\
\text { Square }\end{array}$ & F ratio & Significance \\
\hline Regression & 457.88920 & 1 & 457.88920 & \multirow{2}{*}{ (1) } & \multirow{2}{*}{0.0034} \\
\hline Residual & 14808.23201 & 118 & 231.37863 & 21.643 & \\
\hline Total & 15266.12 & 119 & & & \\
\hline
\end{tabular}

The results in table 8 have a multiple correlation of 0.17319 for emotional achievement relationship in Economics. This figure makes a variance contribution of $1.48 \%$ to the students' achievement as shown by R $2=0.1484$. Again, the $\mathrm{F}$ - ratio at the base of table 8 tries to explain the significance of the hypothesis. However, the ANOVA result in table 9 indicates a significance case, hence, there is a significant relationship between students' emotional engagement and achievement in Economics.

\section{Summary of Findings}

From the analyses of data collected from the field for this study, as presented in this chapter, the major finding that emerged are as follows:

1) Generally the students reported only high and moderate engagement.

2) Most of the students reported high engagement in behavioural and emotional, but moderate engagement in the cognitive type.

3) There is a significant relationship between the three types of engagement (behavioural, cognitive and emotional engagements) and achievement of students in Economics.

\section{Discussion of Results}

\section{Students' Behavioural Engagement as a Determinant of their Achievement in Economics}

From the findings of the study, it was observed that all the items identified in behavioural engagement section in table 1 , were accepted by all the students, with mean values above 2.50 and a grand mean value of 3.00 . Also, since all the students scored above $50 \%$ in the economics achievement test administered to them, it therefore, mean that students behavioural engagement determines their achievement in economics. This is in-line with the findings of Fredriks et al (2004) that there is a significant relationship between behavioural engagement and academic achievement. This 


\section{International Journal of Science and Research (IJSR) \\ ISSN (Online): 2319-7064 \\ Index Copernicus Value (2013): 6.14 | Impact Factor (2015): 6.391}

means that the more behaviourally engaged a student is the better he/she achieves at school.

Furthermore, the hypothesis on behavioural engagement and achievement in economics shows that there is a significant relationship in the mean response of students between behavioural engagement and achievement in economics, as shown in the regression summary of table 4 and the ANOVA result in table 5, where 0.0000 significance was obtained.

\section{Students' Cognitive Engagement as a Determinant of their Achievement in Economics \\ Looking at the findings of the study in table 2, among the 9 items on cognitive engagement, 4 items (items 11, 15, 18 and 19) were rated poor (rejected) by the respondents as not part of the cognitive engagement that promotes/determines their achievement in economics. Meanwhile, the other 5 items were accepted and haven obtained a grand mean of 2.66 , from the section and also haven scored above $50 \%$ in the economics achievement test, it shows that students cognitive engagement determines their achievement in economics. This although is partially in-line with the idea of NCSE (2006b) but contrary to the fact that he said "cognitive engagement was more consistently correlated with achievement than the other two types of engagement", haven recorded the least mean value among the various types of engagement. This may be as a result of poor items identified because according to Fredrick, et al (2002), evidence of a relationship between cognitive engagement and achievement is much stronger than in behavioural and emotional engagement. Cognitive engagement correlates with reading.}

Based on the hypothesis on cognitive engagement and achievement in economics, the result from regression in table 6 and ANOVA summary of table 9 showing 0.0016 significance obtained, means that there is a significant relationship in the mean response of student between cognitive engagement and achievement in economics.

\section{Students' Emotional Engagement as a Determinant of their Achievement in Economics.}

From the findings of the study in table 3, 2 items (21 \& 27) among the eleven identified items were rejected while the other 9 items were accepted with mean values of above 2.50 . Also a grand mean of 2.92 was obtained and haven recorded above $50 \%$ score in the economic achievement test by all the student, it shows that students emotional engagement determines their achievement in economics. This is in-line with the view of Fredrick et al (2002) that emotional engagement is related to achievement but has a little link to achievement. To support this ascertain, NCSE (2006b) concludes that they found a link between behavioural and achievement as well as cognitive and achievement but that emotional engagement was more highly correlated with attendance than with achievement.

The result of the hypotheses on emotional engagement and achievement in economics, reveals positive from the regression analysis in table 8 as well as the ANOVA summary in table 9 which has 0.0034 significance meaning that there is a significant relationship in the mean response of students between emotional engagement and achievement in economics.

\section{Conclusions}

1) Since the three engagement types had mean scores above 2.50 , it is therefore concluded that the more engaged a student is, the better he/she achieves in school.

2) There is a high engagement among senior secondary school students in the state. Out of the three engagement types measured, the students reported moderate in cognitive but high in behavioural and emotional engagements. One can therefore conclude that moderate engagement may be sufficient for a good academic achievement.

3) The levels of behavioural and emotional engagement of the students seem to agree with each other more than cognitive engagement.

\section{Recommendations}

Based on the findings of this study the following recommendations are made:-

1) A campaign that focuses on the importance of school and the consequences of disengagement from school should be carried out regularly by the government agencies and other stakeholders in education. This regular campaign will not only promote students' confidence in their ability to learn and succeed in school but will also help them to see the link between succeeding in school and succeeding in life

2) Small learning communities should be created to foster personalized and continuous relationship between teachers and students. Large schools can be broken down into smaller, connected but somewhat autonomous units to increase the interactions and connections among students and between students and teachers. In this way student engagement will be greatly enhanced.

3) The teacher student ratio should be lowered from its present $1: 40$ to at most $1: 30$ to enable teachers to effectively detect and follow up students exhibiting signs of disengagement from school. The fewer the number of students in a teacher's charge, the more effectively the teacher can monitor them. This may mean employment of more teachers and guidance counsellors.

\section{References}

[1] Adeyemi, S. F. (2011). What is school connectedness? Retrieved June 29, 2007 at http: Wwww.actforyouth.net/?schoolconnectedness.

[2] Al-Methen, C. \& Wilkinson, J (1992). The relationship between feelings of connection to school and achievement, ethnicity and counseling interventions. Retrieved June 29, 2007 from Portland State University, counsellor Education; School counseling specialization, school counseling in Action, Intern projects 2004 from www.ed.pdx.edu/coun/sca.htm. 


\section{International Journal of Science and Research (IJSR) ISSN (Online): 2319-7064 \\ Index Copernicus Value (2013): 6.14 | Impact Factor (2015): 6.391}

[3] Anderson, A.R., Christenson, S.L. \& Lehr, C.A. (2004) School completion and student engagement: Information and strategies for educators. Bethesda: National Association of School Psychologists Retrieved June 29, 2007 at www.nasponline.org.

[4] Attah, O.S (2004). Instrumentation in behavioural research: A practical approach. Enugu: Fulladu.

[5] Bomia, L., Beluzo L., Demeester, D., Elander, K., Johnson, M., \& Sheldon, B. (1997). The impact of teaching strategies on intrinsic motivation. ERIC Clearinghouse on Elementary and Early Childhood Education: ED482269 Retrieved June, 24, 2008 at www.ericdigest.org.

[6] Centre for Comprehensive School Reform and Improvement (CCSRI) (2007). Using positive student Engagement to increase student achievemen. Retrieved March 2, 2012 from www.centreforcsri/.org/index.php? option $=$ com.

[7] Education Review Office (ERO), (n.d) Evaluation indicator for education reviews in schools. Retrieved June 28, 2007 at www.E/sch.engagement and effectiveness.htm.

[8] Fafunwa, A.B. (2001) Educational management in Nigeria. in I.N. Nwangwu, E.T. Ehiametalor, M.A. Ogunu \& M. Nwadiani (Eds.) Current issues in educational management in Nigeria. Benin City. Ambik Press Ltd.

[9] Federal Republic of Nigeria (2004). National policy on education ( $4^{\text {th }}$ ed.) Lagos. NERDC Press.

[10] Fletcher, A. (2005). Guide to students as partners in school change. Olympia, W.A Sound out. Retrieved May, 5, 2010 from http:||en.wikipedia.org.

[11] Fredricks, J.A., Blumenfeld, P.C., \& Paris, A.H. (2004) School engagement: Potential of the concept, state of evidence. Review of Educational Research, 74 (1), 59 109.

[12] Joint Admission and Matriculation Board (2008). UME/DE brochure: $2009 / 2010$ academic session: $\left(17^{\text {th }}\right.$ ed.) Lagos: Office of the Registrar.

[13] Kearsley G \& Shneiderman, B.(2000). Engagement theory: A framework for technology-based teaching and learning. Accessed June 9, 2011 at ww.edb.utexas.edu/index.php/.

[14] Kong, O.P., Wong, N.W., \& Lam, C.C. (2003). Student engagement in mathematics: Development of instruments and validation of constructs. Mathematics Education Review Journal. 15(1), 4-21.

[15] Libbey, H.P. (2004). Measuring student relationships to school: Attachment, bonding, connectedness and engagement. Journal of School Health. 74 (7) 274 283.

[16]Lippman, L \& Rivers, A. (2008) Assessing school engagement: A guide for out-of-school time program practitioners. Retrieved March, 25,2009 at www.childtrends.org.

[17] Marks, H.M. (2000). Student engagement in instrumental activity: Patterns in the elementary, middle, and high school years. American Educational Research Journal. 37 (1) 153 - 184.

[18] National Association of State Board of Education, (2002). Youth development programmes show success in reducing risky behaviours: Policy Update. 10 (13). Alexandria. Policy Information Clearing House.
[19] National Center for School Engagement (2006a). Merrill Middle School: School engagement and staff attendance efforts school year 2005 - 2006. Denver: Colorado Foundation for Families and Children.

[20] National Center for School Engagement (2006b). Quantifying school engagement: Research report. Denver: Colorado Foundation for Families and Children.

[21]Newman, F. (1992). Student engagement and achievement in American secondary schools. Teachers college press.

[22] Parikh, M (2008). The relationship between student engagement and academic performance: An exploration of the paradox of InternationL Undergraduates. Unpublished doctorial dissertation, State University of New York at Buffallo. Accessed May, 22012 At http://www.grim.com/en/doc/252797/the relationshiopberween-student.

[23] Russel, V, J., Ainley, M., \& Frydenberg, E. (2005). Schooling issues digest: Student motivation and engagement. Australian Government: Department of Education, Employment and workplace Relations. Retrieved July,8, 2009 athttp://www.dest.gov.au/sectors/school/education/publi cation resources/schooling is

[24] Skinner, E.A. \& Belmont, M.J. (1993). Motivation in the classrooms: Peciprocal effects of teacher behaviour and student engagement across the school year. Journal of Educational Psychology. 85 (40) 571 - 581.

[25] Taylor, J. \& Nelms, L. (2006). School engagement and life chances: 15 year olds in transition. Brotherhood of St. Laurence.

[26] Valentine, T, Milton, J., Lipnevich, A.A. \& Beder, H (2005).Mapping Cognitive Engagement in Adult Literacy Classrooms

[27] West African Examinations Council (2007, May/June) Chief examiners' report (Nigeria) Lagos: Megavons.

[28] West African Examinations Council (2007). Classification of WAEC results. Retrieved December 18, 2009 from www. waec.ng.org.

[29] West African Examinations Council (2008). WAEC releases May-June 2008results. Retrieved December 18, 2009 from www. waec.ng.org.

[30] Willms, J. (2003). Student engagement at school: A sense of belonging and participation: Results from PISA, 2000. Paris: OECD. 